\title{
Influence of Full-fat Soybean Seeds and Hydrolyzed Palm Oil on the Metabolism of Lactating Dairy Cows
}

\author{
Veronika Bellová, Alena Pechová, Rudolf Dvořák, Leoš Pavlata \\ Clinic of Ruminants, Faculty of Veterinary Medicine, University of Veterinary and Pharmaceutical Sciences \\ Brno, Czech Republic
}

Received March 17, 2008

Accepted February 9, 2009

\begin{abstract}
The aim of the study was to compare the influence of fat supplementation in the form of full-fat soybean seeds and hydrolyzed palm oil as energy sources for dairy cows in early lactation.

During the first 8 lactation weeks, 17 dairy cows divided into group $\mathrm{S}(\mathrm{n}=8)$ and group $\mathrm{C}$ $(n=9)$ were observed. The basic diet was the same for both groups. The differences were in the composition of the concentrate mixture, which had a balanced content of nutrients. In group $\mathrm{S}$ the fat source was heat-treated soybean seeds, while in group $C$ the fat source used was hydrolyzed palm oil. The two diets started to be fed on the day of calving. Blood samples were taken weekly $\left(1^{\text {st }}-5^{\text {th }}\right.$ week $)$ and 8 weeks after delivery. At the end of the experiment ruminal fluid was taken.

During the experiment BCS in both groups deteriorated similarly. In group S it decreased from $3.8 \pm 0.2$ to $3.3 \pm 0.3$ and in group $\mathrm{C}$ from $3.5 \pm 0.4$ to $3.1 \pm 0.4$. A better performance of hepatic metabolism was proved in group S. In group S lower concentrations of non-esterified fatty acids were identified in the $3^{\text {rd }}\left(0.96 \pm 0.38\right.$ vs. $\left.1.76 \pm 0.63 \mathrm{mmol} \cdot \mathrm{l}^{-1} ; p<0.01\right)$ and $8^{\text {th }}(0.32$ \pm 0.29 vs. $\left.0.78 \pm 0.48 \mathrm{mmol} \cdot \mathrm{l}^{-1} ; p<0.05\right)$ week after calving. The gamma-glutamyl transferase (EC 2.3.2.2) activity in serum indicates a better liver parenchyma condition in group $\mathrm{S}$ where no increased activity was identified above the reference range. An increased activity was identified in group $\mathrm{C}$ from the $2^{\text {nd }}$ week with a significant difference between groups detected in the $2^{\text {nd }}(0.41$ \pm 0.07 vs. $\left.0.66 \pm 0.25 \mu \mathrm{kat} \cdot \cdot^{-1} ; p<0.05\right)$ and $4^{\text {th }}\left(0.42 \pm 0.05\right.$ vs. $\left.0.64 \pm 0.25 \mu \mathrm{kat} \cdot 1^{-1} ; p<0.05\right)$ weeks after delivery. There were no significant differences found between groups in bilirubin and aspartate transaminase (EC 2.6.1.1) but a general tendency toward lower values is apparent in group $\mathrm{S}$. No significant differences were found between groups by the examination of ruminal fluid.

Based on these results we can conclude that full-fat soy was better utilised than hydrolysed palm oil and represents a suitable alternative for increasing energy concentration in the diet for dairy cows. On the other hand, the development of liver steatosis in cows make controversial the usage of fat as an energy source for fresh cows even if their BCS is around 3.5-3.8 and it may not be recommended generally.
\end{abstract}

Soy, liver, lipid mobilization, blood, BCS, isoenzymes $L D H$

Lack of energy is the main limiting factor to high yields of dairy cows. Taking into account the low intake of dry matter and the fast increase of milk production in dairy cows after calving, it is important to provide a high energy concentration in the diet during this period. One possibility of solving the energy deficit in dairy cows in this period is to use supplementary fats. The main reason for using fat is its 2-3 times higher energy content compared to saccharides or proteins. The source of fat for dairy cows should have a high content of pure energy, high digestibility, acceptable palatability and price and should be easily manipulated. Fat in the diet can come from different sources, such as natural fat from the basic components (about 3\%), fat from full-fat oil seeds, vegetable oil and inert, or by-pass fat. The effects of untreated fats, also called unprotected fats, are unfavourable on fermentation processes in the rumen. Their effect mainly relates to the unsaturated fatty acids content. Vegetable oils have a higher content of unsaturated fatty acids, and therefore have a higher negative impact on ruminal fermentation. They decrease fibre digestibility and suppress hydrolytic and synthetic processes in rumen.

Address for correspondence:

Doc. MVDr. Alena Pechová, CSc., Dipl. ECBHM

Clinic of Ruminants, Faculty of Veterinary Medicine

University of Veterinary and Pharmaceutical Sciences Brno

Palackého 1-3, 61242 Brno

Czech Republic
Phone: +420 541562408

Fax.: +420541562413

E-mail: pechovaa@vfu.cz

http://www.vfu.cz/acta-vet/actavet.htm 
This is clinically manifested by diarrhoea, lack of appetite and weight loss (Vrzgula et al. 1990; Emery et al. 1995).

The treated fats, or by-pass fats, are processed with the aim of reducing or possibly eliminating their negative effect on rumen fermentation. The purpose of the treatment is to prevent a greater contact of supplementary fats with rumen microorganisms and a fermentation medium. In addition to that, the treatment provides a certain degree of fat resistance to lipolytic hydrogenation by rumen microorganisms. Inertness of fats either depends on natural protection of whole seeds, hydrogenation of fats and thereby reduction of the unsaturated fatty acid level, or on the production of calcium salts or fatty acid amides that are resistant to biohydrogenation activities of ruminal microorganisms. Lundy et al. (2004) found that fatty acid amides are even more resistant in the ruminal environment than calcium salts of fatty acids.

The heat-treated full-fat soy is recommended as an ingredient in diets for high-production dairy cows. Being rich in fat (15-20\%), soy significantly increases the energy value of the diet. Moreover, it has the highest amount of proteins of all legumes (approximately $35 \%$ ) and also the highest lysine content in its protein, up to $2.7 \%$ in the seed dry matter. Soy protein is sometimes called vegetative casein, very similar to milk casein. However, soy also contains antinutritional substances called antitrypsins that block the efficiency of digestive enzymes. These substances are inactivated by heat treatment, which in addition increases protein usability and soy resistance to microbial degradation of proteins in rumen (Kudrna et al. 1998; Tice et al. 1993).

Energizer is a hydrolyzed palm oil made up of long saturated free fatty acid chains. During digestion it is not degraded in the rumen and therefore does not affect fibre digestibility and fermentation in the rumen and it is highly digestible in the small intestine where it arrives almost unaffected.

Soy addition has a positive influence on the feed intake (M'hamed et al. 2001), essential amino acid content in blood (Metcalf et al. 1996), milk yield (Tice et al. 1993, Metcalf et al. 1996; M'hamed et al. 2001), protein content (Metcalf et al. 1996; M'hamed et al. 2001) and fat content in milk (M'hamed et al. 2001). Heat-treated soy increases digestibility of fatty acids in the digestive tract (Tice et al. 1994) and increases the content of polyunsaturated fatty acids in milk (Tice et al. 1994; Abel-Caines et al. 1998). When feeding a high amount of soy equalling $30 \%$ of supplementary diet, a negative impact was found by Pereira et al. (1998ab) of a decrease in the feed intake and fat content in milk. Veira et al. (2001) describe a negative impact on fibre digestibility, milk yield, protein content and particularly substantial decrease in the fat content in milk when feeding soy oil at the amount of $3 \%$ of the total diet.

This project is based on the results of an experiment which has proved a negative effect of a higher fat content (6.9\% of dry matter) in the diet on the hepatic steatosis development (Lubojacká et al. 2005; Pechová et al. 2006). The monitoring focused on comparing the effects of fat supplementation at a lower concentration $(5.3 \%$ of dry matter $)$ in the form of full-fat soybean seeds and hydrolyzed palm oil as energy sources on dairy cow metabolism in early lactation.

\section{Materials and Methods}

The study was undertaken on a herd of Black Pied Lowland cattle with an average milk yield of 7700 1. Dairy cows were placed in loose housing with a group mixed feeding system. Seventeen dairy cows were included in the experiment, divided into group $S(n=8)$ and group $C(n=9)$ in such a way that the two groups were balanced in terms of age and performance. Three primiparous cows were included in each group. Group $\mathrm{C}$ had an average performance of $7686 \pm 10581$ for the last lactation and an average age of $1.89 \pm 0.74$ lactations, dairy cows of group S had a $7683 \pm 994.41$ average performance and an average age of $1.88 \pm 0.78$ lactations. The dairy cows were followed from delivery to the end of the $2^{\text {nd }}$ month of lactation. From delivery the cows were fed two types of diets. The basic diet was the same for both groups and consisted of $14 \mathrm{~kg}$ maize silage, $10 \mathrm{~kg}$ 
pressed silaged beet cuttings, $5 \mathrm{~kg}$ lucerne silage, $2 \mathrm{~kg}$ lucerne hay and $0.2 \mathrm{~kg}$ barley straw. The differences were in the composition of concentrate mixture which was prepared in such a way that the diet for both groups has a balanced nutrient content. The concentrate mixture was given in portions of $9 \mathrm{~kg}$ per dairy cow with a $301 \mathrm{milk}$

Table 1. Composition of feeding mixture ( $\%$ of raw material) for the experimental and control groups

\begin{tabular}{|l|c|c|}
\hline & Group S & Group C \\
\hline Barley grain & 8.00 & 20.00 \\
\hline Maize & 21.61 & 13.56 \\
\hline Wheat & 10.00 & 10.25 \\
\hline Extr. rape grouts & 15.00 & 15.50 \\
\hline Extr. soy grouts & 11.00 & 23.00 \\
\hline Soybeans & 22.00 & - \\
\hline Vitex yeast & 5.50 & 6.00 \\
\hline Feed urea & 0.19 & 0.19 \\
\hline Palm oil & - & 4.48 \\
\hline Mineral supplements* & 6.70 & 6.70 \\
\hline
\end{tabular}

*Content per kg: Ca 155.5 g, P 49.6 g, Na 65.4 g, Cl 81.8 g, Mg 83.8 g, Mn 2490 mg, Zn 2993 mg, Cu 362 mg, I 43 mg, Se $20 \mathrm{mg}$, Co $16 \mathrm{mg}$

Table 2. Concentration of nutrients in the feeding mixture of groups $\mathrm{S}$ and $\mathrm{C}$

\begin{tabular}{|c|c|c|}
\hline & Group S & Group C \\
\hline Dry matter & 902.2 & 898.9 \\
\hline Crude protein $\left[\mathrm{g}^{\circ} \mathrm{kg}^{-1}\right]$ & 247.9 & 246.4 \\
\hline$\left[\mathrm{g} \cdot \mathrm{kg}^{-1}\right]$ & 139.7 & 130.5 \\
\hline$\left[\mathrm{g} \cdot \mathrm{kg}^{-1}\right]$ & 65.8 & 68.4 \\
\hline$\left[\mathrm{g} \cdot \mathrm{kg}^{-1}\right]$ & 47.0 & 48.0 \\
\hline$\left[\mathrm{g} \cdot \mathrm{kg}^{-1}\right]$ & 264.0 & 277.8 \\
\hline$\left[\mathrm{g} \cdot \mathrm{kg}^{-1}\right]$ & 49.8 & 49.9 \\
\hline$\left[\mathrm{MJ} \cdot \mathrm{kg}^{-1}\right]$ & 7.3 & 7.4 \\
\hline Calcium & 15.4 & 15.2 \\
\hline Phosphorus & 8.5 & 8.3 \\
\hline Sodium & 5.3 & 5.3 \\
\hline Magnesium & 5.7 & 5.5 \\
\hline
\end{tabular}

Table 3. Concentration of nutrients in the diet of dairy cows with milk yield of 30 litres

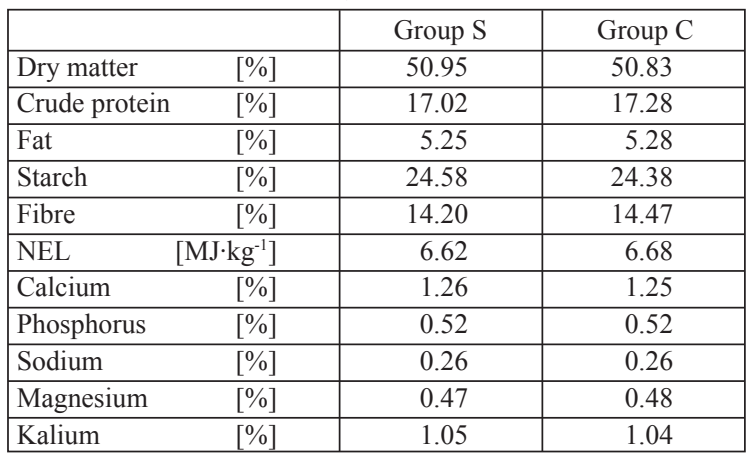
performance. Dairy cows were fed this diet twice a day. In the feed mixture for group $\mathrm{S}$ the source of fat were soybean seeds after hydrothermic treatment by JET SPLODER (VK-Drcman, Czech Republic). Group C was given a diet commonly fed on the farm, in which hydrolyzed palm oil (Energizer RP 10, IFFCO, Malaysia) was used as the fat source. The composition and content of nutrients in the feeding mixture is provided in Tables 1 and 2 and the nutrient content in the diet of dairy cows in Table 3 .

The health of cows was regularly checked by clinical examination. Their physical condition was monitored one week before delivery and further in $2^{\text {nd }}, 4^{\text {th }}$ and $8^{\text {th }}$ weeks after delivery. BCS (body condition score) evaluation was performed using a five-point scale divided by point quarters. Score 1 corresponds to a lean cow and score 5 to an obese cow. The metabolism of dairy cows was followed based on blood sample examination, the blood being sampled at weekly intervals from week 1 to week 5 and, at the trial's end, in week 8 after delivery. The rumen fluid was also examined at the end of the trial. It was sampled with an esophageal tube using suction and the following indicators were established: $\mathrm{pH}$, whole acidity, ciliate protozoa, ammonia and volatile fatty acids (acetic acid, propionic acid, butyric acid and valeric acid). The rumen fluid samples were preserved by toluene for determining volatile fatty acids, by formaldehyde for determining ciliate protozoa and by mercuric chloride for determining the other indicators ( $\mathrm{pH}$, whole acidity, ammonia). Volatile fatty acids (VFA) were determined by gas chromatography on a Chrom 5 device (Laboratory Instruments, Czech Republic).

The blood samples were taken from v. jugularis into disposable test tubes without anticoagulant addition. The following indicators were identified in blood serum: betahydroxybutyrate (BHB), non-esterified fatty acids (NEFA), total cholesterol (TCH), triacylglycerols (TAG), total bilirubin (TB), total protein (TP), urea, aspartate transaminase EC 2.6.1.1 (AST), $\gamma$-glutamyl transferase EC 2.3.2.2 (GMT), creatine kinase EC 2.7.3.2 (CK), lactate dehydrogenase EC 1.1.1.27 (LDH), isoenzymes LDH 1-5. Fluoride blood was used for glucose determination.

All the biochemical variables were determined in the laboratory of clinical biochemistry at the Clinic of Ruminants of the University of Veterinary and 
Pharmaceutical Sciences Brno. They were determined on a Cobas Mira automatic analyzer (Roche, Switzerland) using the tests listed in parentheses: urea (Urea UV KIN $4 \times 50$, Cat. No. 1307017), total bilirubin (BIL 100, Cat. No. 1105309), triacylglycerols (TGL $4 \times 100$, Cat. No. 1105309), CK (CK NAC $7 \times 15$, Cat. No. 1303801), GMT (GMT KIN 100, Cat. No. 1302082) - the tests were provided by LACHEMA (Czech Republic); glucose ( ${ }^{\mathrm{L} G l u k o s a}$, Cat. No. 11601), total protein ( ${ }^{\mathrm{L} P r o t e i n}$ in total (biuret), Cat. No. 12751), total cholesterol ( ${ }^{\mathrm{L} C h o l e s t e r o l,}$ Cat. No.10851), AST ( ${ }^{\mathrm{A} A S T}$, Cat. No. 10351), LDH (LLDH, Cat. No. 12352), - the tests were provided by BIO VENDOR (Czech Republic); NEFA (NEFA, Cat. No. FA 115) and BHB (RANBUT, Cat. No, RB 1008) - the set was provided by RANDOX (Great Britain).

Through electrophoresis on agarose gel LDH isoenzymes were determined (HYDRAGEL ISO - LDH K20) the test provided by SEBIA (France) on a commercial SEBIA device.

The data were processed by F-test for the assessment of variations in individual sets and, in dependence on the results, by double-tailed Student's $t$-test for sets with equal/unequal variations using the EXCEL software.

Statistical evaluation of obtained data is in the tables as mean (x) and standard deviation (SD).

Local Ethics Committee aproved the experimental protocol.

Body condition score

\section{Results and Discussion}

At the time of trial preparation the dairy cows on the farm were mostly in a very good condition (Fig. 1). The condition of group S was somewhat better in the pre-delivery period $(3.84 \pm 0.21)$ compared to group C $(3.53 \pm 0.38)$. During the course of the trial the difference between groups remained at a similar level, and within 8 weeks of the experimental period the condition of group S deteriorated by 0.5 point and that of group C by 0.45 point. A significant difference $(p<0.05)$ between the groups in the condition of cows was only found 2 weeks after delivery, when cows from group $\mathrm{C}$ lost more weight. The monitoring of changes of the cows' condition in the peripartal period presents an important control mechanism of evaluating energy reserves in the body and is widely used in evaluating the body condition of dairy cows (Wildman et al. 1982; Hady et al. 1994). A greater deterioration in physical condition during the dry period and the first period of lactation results in the increased incidence of metabolic disorders, mainly of abomasal dislocation,

ketosis and postparturient hypocalcaemia (Kim and Suh 2003).

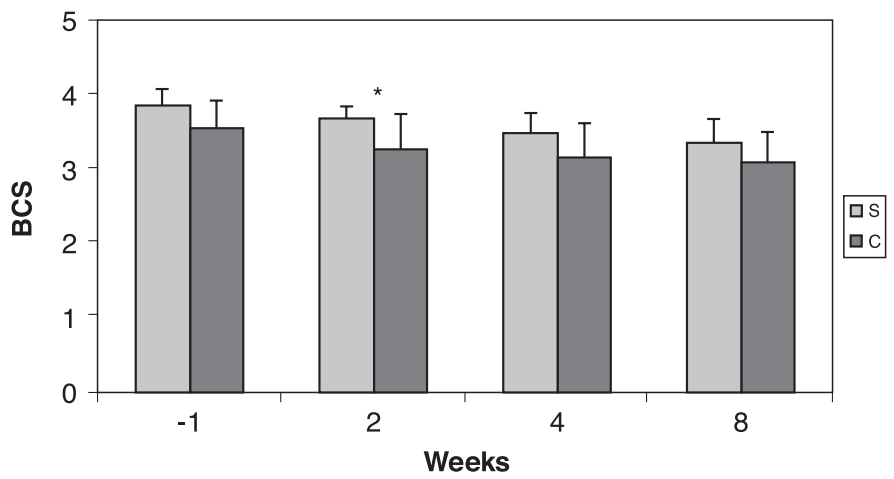

Fig. 1. Evaluation of body condition score with a five-point scale (BCS) in group S and group C from 1 week before delivery to 8 weeks after delivery

Energy metabolism

The variables characterizing energetic metabolism are given in Table 4. All dairy cows developed an energetic deficit and lipid mobilization syndrome in the postpartum period.

The glucose concentration during the period of 5 weeks after delivery fell below 3.0-3.9 $\mathrm{mmol} \cdot \mathrm{l}^{-1}$ of physiological values (Vrzgula et al. 1990), though no significant differences were found between groups in any sampling instance. The glucose only rose above 
Table 4. Selected serum indicators of energy and nitrogen metabolism in group $\mathrm{S}(\mathrm{n}=8)$ and group $\mathrm{C}(\mathrm{n}=9)$ during the first 2 months of lactation

\begin{tabular}{|c|c|c|c|c|c|c|c|}
\hline \multicolumn{2}{|l|}{ Weeks after delivery } & 1 & 2 & 3 & 4 & 5 & 8 \\
\hline \multirow{2}{*}{ Glucose $\left[\mathrm{mmol} \cdot \cdot^{-1}\right]$} & $\mathrm{S}$ & $2.55 \pm 1.22$ & $2.61 \pm 0.89$ & $2.32 \pm 1.19$ & $2.97 \pm 0.34$ & $2.66 \pm 0.47$ & $3.21 \pm 0.39$ \\
\hline & $\mathrm{C}$ & $2.60 \pm 1.06$ & $2.56 \pm 0.76$ & $2.76 \pm 0.48$ & $2.81 \pm 0.59$ & $2.44 \pm 0.95$ & $3.22 \pm 0.44$ \\
\hline \multirow{2}{*}{$\mathrm{BHB}\left[\mathrm{mmol} \cdot \mathrm{l}^{-1}\right]$} & $\mathrm{S}$ & $1.48 \pm 1.32$ & $1.12 \pm 0.77$ & $1.13 \pm 1.04$ & $1.10 \pm 0.59$ & $0.96 \pm 0.71$ & $0.68 \pm 0.09 *$ \\
\hline & $\mathrm{C}$ & $1.41 \pm 1.05$ & $1.37 \pm 0.95$ & $1.14 \pm 0.50$ & $1.36 \pm 1.08$ & $0.66 \pm 0.64$ & $0.52 \pm 0.17^{*}$ \\
\hline \multirow{2}{*}{$\mathrm{NEFA}\left[\mathrm{mmol} \cdot \mathrm{l}^{-1}\right]$} & $\mathrm{S}$ & $1.84 \pm 0.41^{*}$ & $1.42 \pm 0.55$ & $0.96 \pm 0.38 * *$ & $0.77 \pm 0.43$ & $1.05 \pm 0.35$ & $0.32 \pm 0.29 *$ \\
\hline & $\mathrm{C}$ & $1.25 \pm 0.44^{*}$ & $1.44 \pm 0.67$ & $1.76 \pm 0.63^{* *}$ & $1.27 \pm 0.59$ & $0.90 \pm 0.53$ & $0.78 \pm 0.48^{*}$ \\
\hline \multirow{2}{*}{ Cholest. $\left[\mathrm{mmol} \cdot 1^{-1}\right]$} & $\mathrm{S}$ & $2.20 \pm 0.60$ & $2.75 \pm 0.64$ & $4.11 \pm 0.70$ & $4.72 \pm 1.43$ & $4.75 \pm 1.40$ & $6.59 \pm 1.65$ \\
\hline & $\mathrm{C}$ & $2.22 \pm 0.99$ & $3.24 \pm 1.14$ & $4.23 \pm 1.59$ & $4.18 \pm 1.75$ & $5.69 \pm 2.58$ & $6.12 \pm 1.88$ \\
\hline \multirow{2}{*}{$\mathrm{TAG}\left[\mathrm{mmol} \cdot \mathrm{l}^{-1}\right]$} & $\mathrm{S}$ & $0.16 \pm 0.04 * *$ & $0.11 \pm 0.03^{* *}$ & $0.15 \pm 0.04$ & $0.11 \pm 0.04$ & $0.09 \pm 0.05$ & $0.14 \pm 0.04$ \\
\hline & $\mathrm{C}$ & $0.37 \pm 0.15^{* *}$ & $0.31 \pm 0.13^{* *}$ & $0.17 \pm 0.05$ & $0.14 \pm 0.04$ & $0.11 \pm 0.03$ & $0.13 \pm 0.02$ \\
\hline \multirow{2}{*}{ Total Protein $\left[\mathrm{g} \cdot \mathrm{l}^{-1}\right]$} & $\mathrm{S}$ & $73.08 \pm 8.41$ & $74.91 \pm 9.29$ & $79.45 \pm 6.31$ & $78.94 \pm 6.63$ & $76.40 \pm 7.25$ & $80.91 \pm 4.98$ \\
\hline & $\mathrm{C}$ & $63.13 \pm 10.67$ & $75.31 \pm 6.23$ & $77.42 \pm 7.53$ & $74.49 \pm 7.69$ & $78.98 \pm 6.12$ & $80.87 \pm 4.46$ \\
\hline \multirow{2}{*}{ Urea $\left[\mathrm{mmol} \cdot 1^{-1}\right]$} & $\mathrm{S}$ & $3.22 \pm 0.56$ & $2.75 \pm 0.86$ & $3.00 \pm 1.22 * *$ & $3.52 \pm 0.74$ & $3.49 \pm 0.75$ & $2.50 \pm 0.76$ \\
\hline & $\mathrm{C}$ & $3.25 \pm 0.80$ & $3.22 \pm 0.70$ & $4.58 \pm 1.17^{* *}$ & $3.58 \pm 1.00$ & $4.29 \pm 0.60$ & $3.73 \pm 1.50$ \\
\hline
\end{tabular}

$* p<0.05$ (between groups $\mathrm{S}$ and $\mathrm{C}$ )

$* * p<0.01$ (between groups $\mathrm{S}$ and $\mathrm{C}$ )

$3 \mathrm{mmol} \cdot \mathrm{l}^{-1}$ in both groups at the end of the followed period. The energy deficit is also indicated by incidence of ketosis. The BHB concentrations exceeded the physiological range up to $0.6 \mathrm{mmol}^{-1} \mathrm{l}^{-1}$ (Kraft and Dürr 2001) in group $\mathrm{S}$ in the $1^{\text {st }}-5^{\text {th }}$ and the $8^{\text {th }}$ week after delivery and in the group $\mathrm{C}$ in weeks $1-5$ after delivery. In the $8^{\text {th }}$ week after delivery the $\mathrm{BHB}$ concentration in group $\mathrm{S}$ was significantly higher $(p<0.05)$. Also the NEFA concentration exceeded the physiological range of $0.1-0.35 \mathrm{mmol} \cdot 1^{-1}$ in both groups (Vrzgula et al. 1990), in the $1^{\text {st }}-5^{\text {th }}$ week after delivery in group $S$ and in $1^{\text {st }}-5^{\text {th }}$ and the $8^{\text {th }}$ week after delivery in group C. We found significantly higher NEFA concentrations in blood serum in group $\mathrm{S}$ in the $1^{\text {st }}$ week after delivery $(p<0.05)$, but in the $3^{\text {rd }}$ and $8^{\text {th }}$ weeks after delivery the NEFA concentration in group $\mathrm{S}$ was lower $(p<0.01$ and $p<0.05)$. Schroeder et al. (2002) found no effect of partially hydrogenated oil in the amounts of $0,0.5$ and $1 \mathrm{~kg} /$ day on the NEFA concentration in plasma in the dairy cows within the first lactation phase. Mohamed et al. (2002) did not confirm a significant increase of NEFA in dairy cows when feeding calcium salts of fatty acids at the amounts of 0.5 and $10 \%$ of the basic diet. The increase in BHB and NEFA concentrations in blood serum is characteristic of lipid mobilization syndrome development in dairy cows and is one of the factors directly affecting the hepatic steatosis development. Evaluating our trial, it is surprising to some degree that lower NEFA concentrations were found in group $\mathrm{S}$ of cows whose condition was better and therefore more extensive lipid mobilization could be expected in them. These results would indicate a better use of energy from soy.

In group $\mathrm{S}$ the TAG concentration was lower $(p<0.01)$ in the $1^{\text {st }}$ and $2^{\text {nd }}$ week after delivery and during the monitored period the values were below the physiological range of $0.17-0.51 \mathrm{mmol} \cdot 1^{-1}$ (Kraft and Dürr 2001). In group C the TAG concentration was below the physiological limit in the $4^{\text {th }}, 5^{\text {th }}$ and $8^{\text {th }}$ week after delivery. The TAG concentration decrease indicates increased fat retention in hepatocytes, caused by insufficient synthesis of transport lipoproteins. The lower concentrations of TAG in group $\mathrm{S}$ in the first weeks of the trial were probably due to their very good condition, since fat accumulates in the liver also when cows put on weight. During the trial the TAG concentration in both groups evened out. The effect of physical condition on the TAG concentration was examined by Kim and Suh (2003). The authors compared dairy cows with a slight BCS decrease (by $0-0.75$ point) and those with a serious 
BCS decrease (by 1-1.5 points) before delivery and found no difference in the TAG concentration between the groups.

In the $1^{\text {st }}$ week after delivery the cholesterol concentration in blood in both groups decreased below the reference range of 2.6-5.2 $\mathrm{mmol}^{-1} \mathrm{l}^{-1}$ (Vrzgula et al. 1990), but during the trial it gradually increased in both groups. The values above the reference range were identified in group $\mathrm{S}$ in the $8^{\text {th }}$ week and in group $\mathrm{C}$ in the $5^{\text {th }}$ and $8^{\text {th }}$ weeks after delivery. These results are consistent with our results, Lubojacká et al. (2005), Pechová et al. (2006), where we determined a substantial influence of fat concentration in the diet on cholesterol concentration in blood. This trial aimed to find whether cholesterol concentration in blood was influenced by the type of fat in feed. The total cholesterol concentration was not influenced by the type of fat in the diet. No significant differences were found between groups in any sampling instance. Schroeder et al. (2002) studied the influence of partially hydrogenated oil ( $1 \mathrm{~kg}$ /day vs. $0.5 \mathrm{~kg} /$ day vs. 0$)$ in dairy cows during the first lactation period. They found that when partially hydrogenated oil was fed at the amount of $1 \mathrm{~kg} /$ day, TAG concentration dropped and cholesterol concentration increased in plasma. Other researchers (Espinoza et al. 1995) report increased total cholesterol concentration and TAG as a result of feeding calcium salts of fatty acids (125 g/day vs. 0$)$ in dairy cows during the first lactation period.

Nitrogen metabolism

Total protein concentration was relatively balanced during the trial and gradually increased in both groups (Table 4). The average values in both groups were within the reference range of $60-80 \mathrm{~g} \cdot \mathrm{l}^{-1}$ (Vrzgula et al. 1990).

During the trial the urea concentration was always lower in group S (see Table 4) but a significant difference between groups was identified only in the $3^{\text {rd }}$ week after delivery $(p<0.05)$. There was a rather large individual variability in urea concentration within the different groups. The lower urea concentration in the blood of group $\mathrm{S}$ was probably caused by a larger share of bypass proteins contained in soy. Chen et al. (2002) also identified urea reduction in the plasma of high production dairy cows when given heat-treated soy, as compared to feeding soy grouts and protected fat. McCormick et al. (2001) describes the reduction of plasmatic urea levels in dairy cows given feed rations containing a high percentage of protected protein (6.8\% vs. $5.8 \%$ vs. $5 \%)$.

\section{Liver and muscle enzymes}

During the whole monitored period the total bilirubin concentration (Table 5) was increased above the reference range of $0.17-5.13 \mu \mathrm{mol} \cdot 1^{-1}$ (Vrzgula et al. 1990). No significant differences were found between groups $\mathrm{S}$ and $\mathrm{C}$ in any sampling instance, though a general tendency toward lower values was apparent in group $S$ with the exception of the $1^{\text {st }}$ and $5^{\text {th }}$ weeks. High bilirubin concentration in blood may be caused by a liver disorder, bile duct obstruction or intravascular haemolysis (Reece 1998). Increased bilirubin concentration in blood is also a relatively sensitive indicator of hepatic steatosis (Pechová et al. 1997). Bilirubin concentrations determined by us demonstrate the alteration of liver metabolism in both groups. A tendency to lower values in group $\mathrm{S}$ is somewhat surprising as the experimental cows were overconditioned before calving, and therefore a greater degree of liver damage might have been expected. These results indicate that the liver parenchyma changes were of reversible character and energy from soy was better utilized.

Similarly, the AST activity also shows the liver parenchyma affection in both groups of cows, with a tendency to higher activities identified in group C. The differences between groups were not significant in any sampling instance. AST activity exceeding reference values from $0.72-1.41 \mu \mathrm{kat}^{-1} \mathrm{l}^{-1}$ (Pechová 1992) was determined in both groups during the first five weeks of lactation. AST activity increases in dairy cows with liver steatosis 
Table 5. Enzymatic and hepatic profile in dairy cows of group $S(n=8)$ and group $C(n=9)$ during the first 2 months of lactation

\begin{tabular}{|c|c|c|c|c|c|c|c|}
\hline \multicolumn{2}{|l|}{ Weeks after delivery } & 1 & 2 & 3 & 4 & 5 & 8 \\
\hline \multirow[t]{2}{*}{ Bilirubin $\left[\mu \mathrm{mol} \cdot 1^{-1}\right]$} & $\mathrm{S}$ & $19.49 \pm 4.01$ & $12.68 \pm 4.48$ & $11.06 \pm 4.68$ & $10.38 \pm 3.22$ & $12.23 \pm 4.12$ & $6.19 \pm 0.97$ \\
\hline & $\mathrm{C}$ & $18.17 \pm 8.78$ & $14.40 \pm 6.94$ & $16.00 \pm 6.75$ & $13.18 \pm 5.49$ & $10.01 \pm 2.36$ & $8.61 \pm 2.91$ \\
\hline \multirow[t]{2}{*}{ AST $\left[\mu \mathrm{kat}^{-1} \mathrm{l}^{-1}\right]$} & $\mathrm{S}$ & $2.80 \pm 1.39$ & $2.35 \pm 0.86$ & $1.79 \pm 0.30$ & $1.58 \pm 0.31$ & $1.44 \pm 0.17$ & $1.37 \pm 0.15$ \\
\hline & $\mathrm{C}$ & $3.18 \pm 2.16$ & $2.93 \pm 1.39$ & $2.10 \pm 0.37$ & $1.89 \pm 0.50$ & $1.54 \pm 0.48$ & $1.35 \pm 0.17$ \\
\hline \multirow[t]{2}{*}{ GMT $\left[\mu \mathrm{kat} \cdot \mathrm{l}^{-1}\right]$} & $\mathrm{S}$ & $0.40 \pm 0.07$ & $0.41 \pm 0.07 *$ & $0.44 \pm 0.09$ & $0.42 \pm 0.05^{*}$ & $0.44 \pm 0.03$ & $0.44 \pm 0.06$ \\
\hline & $\mathrm{C}$ & $0.40 \pm 0.08$ & $0.66 \pm 0.25^{*}$ & $0.69 \pm 0.31$ & $0.64 \pm 0.25^{*}$ & $0.67 \pm 0.28$ & $0.64 \pm 0.26$ \\
\hline \multirow[t]{2}{*}{$\mathrm{CK}\left[\mu \mathrm{kat} \cdot \mathrm{I}^{-1}\right]$} & $\mathrm{S}$ & $4.94 \pm 5.36$ & $2.04 \pm 0.83$ & $2.29 \pm 1.33$ & $1.50 \pm 0.54$ & $1.31 \pm 0.45$ & $1.61 \pm 0.28$ \\
\hline & $\mathrm{C}$ & $9.73 \pm 15.77$ & $2.28 \pm 1.71$ & $1.55 \pm 0.39$ & $1.50 \pm 0.41$ & $1.47 \pm 0.32$ & $1.50 \pm 0.25$ \\
\hline \multirow[t]{2}{*}{$\mathrm{LDH}\left[\mu \mathrm{kat} \cdot \mathrm{I}^{-1}\right]$} & $\mathrm{S}$ & $38.73 \pm 6.90$ & $37.17 \pm 6.78$ & $37.96 \pm 7.77 *$ & $34.10 \pm 5.11$ & $32.80 \pm 4.91^{* *}$ & $37.56 \pm 3.76$ \\
\hline & $\mathrm{C}$ & $38.69 \pm 9.92$ & $49.57 \pm 18.71$ & $47.46 \pm 8.90^{*}$ & $43.36 \pm 7.23$ & $43.36 \pm 7.23 * *$ & $39.83 \pm 7.44$ \\
\hline \multirow[t]{2}{*}{ LDH $1[\%]$} & $\mathrm{S}$ & $46.77 \pm 4.14^{*}$ & $45.27 \pm 4.23$ & $47.36 \pm 2.78$ & $47.51 \pm 2.76$ & $49.82 \pm 2.47$ & $48.80 \pm 2.74$ \\
\hline & $\mathrm{C}$ & $40.46 \pm 6.17$ & $43.43 \pm 6.76$ & $45.90 \pm 3.61$ & $46.26 \pm 3.34$ & $47.00 \pm 4.58$ & $48.13 \pm 5.31$ \\
\hline \multirow[t]{2}{*}{ LDH 2 [\%] } & $\mathrm{S}$ & $27.41 \pm 2.17$ & $27.69 \pm 2.76^{* *}$ & $27.31 \pm 1.91 * *$ & $27.59 \pm 1.16^{* *}$ & $26.83 \pm 0.87$ & $25.60 \pm 0.78$ \\
\hline & $\mathrm{C}$ & $28.49 \pm 3.61$ & $31.01 \pm 1.65^{* *}$ & $30.21 \pm 1.70^{* *}$ & $30.08 \pm 2.06^{* *}$ & $28.60 \pm 2.24$ & $26.25 \pm 0.91$ \\
\hline \multirow[t]{2}{*}{ LDH $3[\%]$} & $\mathrm{S}$ & $16.91 \pm 2.74$ & $17.21 \pm 2.23$ & $15.89 \pm 1.51$ & $15.83 \pm 1.44$ & $14.85 \pm 1.10$ & $14.86 \pm 1.39$ \\
\hline & $\mathrm{C}$ & $18.26 \pm 3.08$ & $17.56 \pm 4.24$ & $16.05 \pm 2.18$ & $15.63 \pm 2.12$ & $15.09 \pm 2.46$ & $15.50 \pm 3.28$ \\
\hline \multirow[t]{2}{*}{ LDH $4[\%]$} & $\mathrm{S}$ & $5.49 \pm 1.17$ & $6.13 \pm 1.94$ & $5.81 \pm 1.74$ & $5.69 \pm 1.68$ & $5.45 \pm 0.87$ & $6.75 \pm 1.52$ \\
\hline & $\mathrm{C}$ & $6.23 \pm 1.39$ & $5.05 \pm 1.86$ & $5.24 \pm 1.98$ & $5.21 \pm 1.74$ & $5.58 \pm 1.72$ & $6.13 \pm 1.30$ \\
\hline \multirow[t]{2}{*}{ LDH $5[\%]$} & $\mathrm{S}$ & $3.41 \pm 0.89$ & $3.73 \pm 1.50$ & $3.69 \pm 1.10$ & $3.36 \pm 0.50$ & $2.63 \pm 1.11$ & $3.60 \pm 0.37$ \\
\hline & $\mathrm{C}$ & $6.56 \pm 8.35$ & $2.95 \pm 1.05$ & $2.59 \pm 0.85$ & $2.83 \pm 1.02$ & $3.74 \pm 1.32$ & $3.98 \pm 1.15$ \\
\hline
\end{tabular}

$* p<0.05$ (between groups $\mathrm{S}$ and $\mathrm{C}$ )

** $p<0.01$ (between groups $\mathrm{S}$ and $\mathrm{C}$ )

Table 6. Variables of ruminal fluid in dairy cows of group $\mathrm{S}$ $(n=8)$ and group $C(n=9)$ in the $8^{\text {th }}$ week of lactation

\begin{tabular}{|c|c|c|}
\hline & & 8 weeks after delivery \\
\hline \multirow{2}{*}{$\mathrm{pH}$} & $\mathrm{S}$ & $6.37 \pm 0.32$ \\
\hline & $\mathrm{C}$ & $6.38 \pm 0.30$ \\
\hline \multirow{2}{*}{ Total acidity [titr. u.] } & $\mathrm{S}$ & $22.37 \pm 6.24$ \\
\hline & $\mathrm{C}$ & $22.29 \pm 5.57$ \\
\hline \multirow{2}{*}{ Number of protozoa $\left[.10^{3} \cdot \mathrm{ml}^{-1}\right]$} & $\mathrm{S}$ & $243.4 \pm 80.1$ \\
\hline & $\mathrm{C}$ & $251.6 \pm 52.4$ \\
\hline \multirow{2}{*}{$\mathrm{NH}_{3}\left[\mathrm{mmol} \cdot \cdot^{-1}\right]$} & $\mathrm{S}$ & $2.90 \pm 2.26$ \\
\hline & $\mathrm{C}$ & $3.52 \pm 1.36$ \\
\hline \multirow{2}{*}{$\mathrm{VFA}\left[\mathrm{mmol} \cdot \cdot^{-1}\right]$} & $\mathrm{S}$ & $105.7 \pm 18.6$ \\
\hline & $\mathrm{C}$ & $113.1 \pm 17.9$ \\
\hline \multirow{2}{*}{ acetic acid $[\mathrm{mol} \%]$} & $\mathrm{S}$ & $61.36 \pm 4.57$ \\
\hline & $\mathrm{C}$ & $59.16 \pm 5.04$ \\
\hline \multirow{2}{*}{ propionic acid [mol\%] } & S & $20.81 \pm 4.59$ \\
\hline & $\mathrm{C}$ & $23.28 \pm 4.27$ \\
\hline \multirow{2}{*}{ n-butyric acid [mol\%] } & $\mathrm{S}$ & $14.71 \pm 0.88$ \\
\hline & $\mathrm{C}$ & $13.99 \pm 1.34$ \\
\hline \multirow{2}{*}{ i-butyric acid [mol\%] } & $\mathrm{S}$ & $0.93 \pm 0.15$ \\
\hline & $\mathrm{C}$ & $1.14 \pm 0.30$ \\
\hline \multirow{2}{*}{ n-valeric acid [mol\%] } & $\mathrm{S}$ & $1.31 \pm 0.34$ \\
\hline & $\mathrm{C}$ & $1.69 \pm 0.77$ \\
\hline \multirow{2}{*}{ i-valeric acid [mol\%] } & $\mathrm{S}$ & $0.84 \pm 0.15$ \\
\hline & $\mathrm{C}$ & $0.78 \pm 0.29$ \\
\hline
\end{tabular}

(Pechová et al. 2002), in cases of energy metabolism disorder, damage to parenchymatous organs or reproduction disorders (Kupczyński et al. 2002).

GMT activity in blood serum indicates a better liver parenchyma condition in group $\mathrm{S}$ where no increased activity was found above the reference range of $0.14-0.55$ $\mu \mathrm{kat} \cdot \mathrm{l}^{-1}$ (Pechová 1992) in any sampling instance. In contrast, increased activity was found in group $\mathrm{C}$ from the $2^{\text {nd }}$ week to the end of the monitored period, with a significant difference between groups detected in the $2^{\text {nd }}$ and $4^{\text {th }}$ weeks after delivery. These results indicate a smaller extent of liver parenchyma damage in group S. GMT activity increases in cases of damage to hepatocytic cell structure (Kupczyński et al. 2002) and affection of bile ducts (Kraft and Dürr 2001).

LDH activity in blood serum was 
lower in group S during the whole followed period, with significant differences identified in the $3^{\text {rd }}(p<0.05)$ and $5^{\text {th }}(p<0.01)$ weeks after delivery. During the whole monitored period LDH activities were higher than the reference range of 16.3-29.0 $\mu \mathrm{kat} \cdot \mathrm{l}^{-1}$ (Pechová 1992). LDH is a cytoplasmatic enzyme acting as a sensitive indicator of cell membrane damage. Total LDH activity is the greatest in the heart, liver and kidneys (Yasuda et al. 1989). LDH increases in relation to insufficient ATP content, due to fat droplet accumulation in hepatocytes, subclinical acidosis, hypoxia (Asefa Asmare et al. 1999) and with the increasing extent of hepatic steatosis (Pechová et al. 1997).

Isoenzymatic LDH model was studied with the aim of differentiation of the causes of LDH increase. LDH 1, LDH 2 and LDH 3 isoenzymes mostly occur in tissues with aerobic metabolism, in ruminants mainly in the heart, liver, kidneys and blood serum. LDH 4 and LDH 5 isoenzymes dominate in tissues with anaerobic metabolism, mainly in striated muscles (Yasuda et al. 1989). Within our monitoring, a higher LDH 1 activity $(p<0.05)$ in group $\mathrm{S}$ was identified in the $1^{\text {st }}$ week after delivery and a LDH 2 lower activity $(p<0.01)$ in $2^{\text {nd }}-4^{\text {th }}$ weeks after delivery. These results are consistent with other indicators and demonstrate a lower extent of liver parenchyma damage in group S. In hepatic steatosis LDH 2 activity is increased and LDH 1 decreases (Yasuda et al. 1989; Pechová 1992). On the other hand, meat cattle develop higher LDH 4 and LDH 5 activities as a result of a larger muscle volume (Sobiech et al. 2002). Asefa Asmare (1998) also describes a positive correlation between LDH 1 activity and animal productivity. Yasuda et al. (1989) identified increased LDH 1 and LDH 2 activities due to liver tissue degeneration. Asefa Asmare et al. (1999) describe increased LDH 4 and LDH 5 activities in relation to liver damage. Šutiaková et al. (2004) state an increased LDH 5 activity in relation to muscle tissue damage and hepatocellular damage. It clearly follows from the above overview that the changes to the LDH enzyme model are widely varied and although the results reached by individual authors are not consistent, they may indicate pathophysiological changes in the body.

Beside the other enzymes creatine kinase was followed for the purpose of evaluating the level of muscle alteration. Increased activity of this enzyme was found in both groups in the first week after delivery only, which was probably related to the delivery itself. No increased activity was found in the following samplings and similar values were found in both groups. It can be concluded based on these samplings that no serious alternation of muscle tissue (catabolism, dystrophy) took place in dairy cows during the first two months and the identified AST and LDH activities reflected the extent of hepatocyte damage.

\section{Rumen metabolism}

In order to evaluate fermentation processes in the ruminant stomach, rumen fluid (Table 6) was sampled in the final phase of monitoring. The observed indicators were within the physiological range with the exception of ammonia concentration, and no significant differences were found between the groups. In both groups ammonia concentration dropped below the physiological range (5.8-17.6 mmol/1) (Vrzgula et al. 1990). With regard to the latter, there was quite a large individual variability in the two groups. Although the difference between the groups was not significant, group $\mathrm{S}$ had lower ammonia concentrations, which may be caused by a higher proportion of bypass proteins contained in soy. Tice et al. (1993) reached similar monitoring results. These authors identified ammonia reduction in ruminal fluid when feeding heat-treated soy as compared to untreated soy $(19.7 \%$ of basic diet).

In our experiment lipid mobilization syndrome with liver steatosis occurred in cows from both groups. The majority of cows had very good body condition; BCS in group S was on average 0.3 point higher than in the control group. This condition predisposes dairy cows to development of a more severe lipid mobilization syndrome. Despite this unfavourable 
factor, better performance of the liver was determined in group $\mathrm{S}$ fed full-fat soy. Based on these results we can conclude that full-fat soy was better utilised than hydrolysed palm oil and represents a suitable alternative for increasing energy concentration in the diet for dairy cows. On the other hand, the development of liver steatosis in cows makes the usage of fat as an energy source for fresh cows controversial even if their BCS is around 3.5-3.8, and it may not be recommended generally.

\section{Vliv plnotučných semen sóji a hydrolyzovaného palmového oleje na metabolismus dojnic v poporodním období}

Cílem sledování bylo srovnat vliv suplementace tuku ve formě plnotučných semen sóji a hydrolyzovaného palmového oleje jako zdroje energie na metabolismus dojnic na začátku laktace.

Během prvních 8 týdnů laktace bylo sledováno 17 dojnic, rozdělených na skupinu $\mathrm{S}$ $(\mathrm{n}=8)$ a skupinu $\mathrm{C}(\mathrm{n}=9)$. Základní krmná dávka sestávající z objemných krmiv byla u obou skupin dojnic shodná. Rozdíly byly ve složení jadrné krmné směsi, která měla u obou skupin vyrovnaný obsah živin. Ve skupině S byla zdrojem tuku hydrotermicky upravená plnotučná semena sóji ( $22 \%$ doplňkové krmné směsi), ve skupině $C$ byl jako zdroj tuku využíván hydrolyzovaný palmový olej (ve specialitě Energizer). Podávání obou krmných dávek začalo dnem otelení. Týden před otelením a ve 2., 4. a 8. týdnu po porodu byla hodnocena kondice dojnic, vzorky krve byly odebírány v 1. - 5. a 8. týdnu po porodu. Na závěr pokusu bylo provedeno vyšetření bachorové tekutiny.

$\mathrm{V}$ průběhu pokusu bylo zhoršení kondice dojnic u obou skupin obdobné, body condition score (BCS) se snížilo u skupiny S z 3,84 $\pm 0,21$ na 3,34 $\pm 0,3$ a u skupiny $\mathrm{C}$ z 3,53 $\pm 0,38$ na $3,08 \pm 0,39$. BCS bylo u skupiny $\mathrm{S}$ v průměru o 0,3 bodu vyšší než ve skupině $\mathrm{C}$, ale rozdíly nebyly signifikantní. I přes tento nepř́iznivý faktor byl zjištěn lepší stav jaterního parenchymu u skupiny S. Nižší koncentrace neesterifikovaných mastných kyselin byla u skupiny $\mathrm{S}$ ve třetím $\left(0,96 \pm 0,38\right.$ vs. $\left.1,76 \pm 0,63 \mathrm{mmol} \cdot \mathrm{l}^{-1} ; p<0,01\right)$ a osmém týdnu po porodu $\left(0,32 \pm 0,29\right.$ vs. $\left.0,78 \pm 0,48 \mathrm{mmol} \cdot 1^{-1} ; p<0,05\right)$. Aktivita $\gamma$-glutamyltransferázy ukazovala na lepší stav jater u skupiny $\mathrm{S}$, kde nebyly zjišsěny aktivity zvýšené nad referenční hodnoty. Naopak ve skupině $C$ byly zvýšené aktivity zjištěny od 2 . týdne, přičemž signifikantní rozdíly mezi skupinami byly ve druhém $\left(0,41 \pm 0,07 \mathrm{vs} .0,66 \pm 0,25 \mu \mathrm{kat} \cdot \mathrm{l}^{-1}\right.$; $p<0,05)$ a čtvrtém týdnu po porodu $\left(0,42 \pm 0,05\right.$ vs. $\left.0,64 \pm 0,25 \mu \mathrm{kat} \cdot \mathrm{l}^{-1} ; p<0,05\right)$. Signifikantní rozdíly nebyly zjištěny u bilirubinu a aspartátaminotransferázy, ale tendence nižších hodnot byla zřejmá u skupiny S. Vyšetřením bachorové tekutiny nebyly zjištěny mezi skupinami signifikantní rozdíly.

Na základě našich výsledků je zkrmování tepelně upravené sóji v postpartálním období vhodnější alternativou zvýšení koncentrace energie v krmné dávce dojnic než hydrolyzovaný palmový olej. Vzhledem k rozvoji lipomobilizačního syndromu se však podávání tuků v období rozdojování jeví sporné i pro dojnice s BCS kolem 3,5-3,8 a nelze je proto obecně doporučit.

\section{Acknowledgement}

The study was carried out with the support of MSM Project No. 6215712402.

\section{References}

Abel-Caines SF, Grant RJ, Klopfenstein TJ, Winowiski T, Barney N 1998: Influence of nonenzymatically browned soybeans on ruminal fermentation and lactational performance of dairy cows. J Dairy Sci 81: 1036-1045

Asefa Asmare A, Kováč G, Reichel P, Buleca J, Ščuroková E 1998: Serum isoenzyme activity of lactate dehydrogenase in dairy cows at different production stages. Folia Vet 42: 77-81

Asefa Asmare A, Kováč G, Reichel P, Ščuroková E 1999: Serum LDH isoenzymes activity and other constituents to predict liver damage in dairy cows. Czech J Anim Sci 44: 5-12

Emery RS, Dyk PB, Leisman JL, Bucholtz HF, Vandehaar MJ 1995: Prepartum nonesterified fatty acids in plasma are higher in cows developing periparturient health problems. J Dairy Sci 78 (Suppl. 1): 264 
Espinoza L, Ramirez-Godinez JA, Jimenez JA, Flores A 1995: Effects of calcium soaps of fatty acids on postpartum reproductive activity in beef cows and growth of calves. J Anim Sci 73: 2888-2892

Hady PJ, Domecq JJ, Kaneene JB 1994: Frequency and precision of body condition scoring in dairy cattle. J Dairy Sci 77: 1543-547

Chen KJ, Jan DF, Chiou PWS, Yang DW 2002: Effects of dietary heat extruded soybean meal and protected fat supplement on the production, blood and ruminal characteristics of Holstein cows. Asian-Australasian J Anim Sci 15: $821-827$

Kim IH, Suh GH 2003: Effect of the amount of body condition loss from the dry to near calving periods on the subsequent body condition change, occurrence of postpartum diseases, metabolic parameters and reproductive performance in Holstein dairy cows. Theriogenology 60: 1445-1456

Kraft W, Dürr UM 2001: Clinical laboratory diagnostics in veterinary medicine (in Slovak), Bratislava, Hajko \& Hajková, 365 p.

Kupczyński R, Chudoba-Drozdowska B 2002: Values of selected biochemical parameters of cows' blood during their drying-off and the beginning of lactation. Electronic Journal of Polish Agricultural Universities. [cit. 2003-05-28]. Available on-line [http://www.ejpau.media.pl/series/volume5/issue1/veterinary/art-01.html]

Kudrna V et al. 1998: Production of fodders and cattle nutrition. Published by Praha: Agrospoj, $362 \mathrm{~s}$.

Lubojacká V, Pechová A, Dvořák R, Drastich P 2005: Liver steatosis following supplemenation with fat in dairy cows diets. Acta Vet Brno 74: 217-224

Lundy FP, Block E, Bridges Jr WC, Bertrand JA, Jenkins TC 2004: Ruminal biohydrogenation in Holstein cows fed soybean fatty acids as amides or calcium salts. J Dairy Sci 87: 1038-1046

McCormick ME, Redfearn DD, Ward JD, Blouin DC 2001: Effect of protein source and soluble carbohydrate addition on rumen fermentation and lactation performance of Holstein cows. J Dairy Sci 84: 1686-1697

Metcalf JA, Wraycahen D, Chettle EE, Sutton JD, Beever DE, Crompton LA, Macrae JC, Bequette BJ, Backwell FRC 1996: The effect of dietary crude protein as protected soybean meal on mammary metabolism in the lactating dairy cow. J Dairy Sci 79: 603-611

M'hamed D, Faverdin P, Verite R 2001: Effects of the level and source of dietary protein on intake and milk yield in dairy cows. Anim Res 50: 205-211

Mohamed T, Sato H, Kurosawa T, Oikawa S 2002: Bile acid extraction rate in the liver of cows fed high - fat diet and lipid profiles in the portal and hepatic veine. J Vet Med A Physiol Patohol Clin Med 49: 151-156

Pechová A 1992: Diagnostics and prevention of lipomobilization syndrome in postpartum dairy cows (in Czech). Ph.D. Thesis, Univ Vet Pharm Sci Brno, Brno, 170 p.

Pechová A, Illek J, Halouzka R 1997: Diagnosis and control of the development of hepatic steatosis in dairy cows in the periparturient period. Acta Vet Brno 66: 235-243

Pechová A, Illek J, Pavlata L 2002: Einwirkungen der Lebersteatose auf den Stoffwechsel bei Milchkühen. Wien Tierärztl Mschr 89: 325-332

Pechová A, Dvořák R, Drastich P, Lubojacká V, Pavlata L, Poul J 2006: Influence of increased lipid content in diet in the form of treated rapeseed meal on the metabolism and milk yield of dairy cows in the first third of lactation. Vet Med 51: 346-356

Pereira CMD, da Silva JFC, Valadares SD, Campos JMD, Cecon PR 1998a: Ground soybean seed in the lactating cows diets. 1. Intake and digestibility of nutrients. Revista Brasileira de Zootecnia - Brazilian J Anim Sci 27: 1218-1224

Pereira CMD, da Silva JFC, Valadares SD, Campos JMD, Cecon PR 1998b: Ground soybean seed in the lactating cows diets. 2. Milk production and composition. Revista Brasileira de Zootecnia - Brazilian J Anim Sci 27: $1225-1233$

Reece W 1998: Domestic Animals Physiology. Published by Praha: Grada Publishing. 456 p.

Schroeder GF, Gagliostro GA, Becu-Villalobos D, Lacau-Mengido I 2002: Supplementation with partially hydrogenated oil in grazing dairy cows in early lactation. J Dairy Sci 85: 580-594

Sobiech P, Kuleta Z, Jałyński M 2002: Serum LDH isoenzyme activity in dairy and beef cows. Med Vet 1: 3943

Šutiaková I, Šutiak V, Krajničáková M, Bekeová E 2004: Alterations of LDH and its isoenzyme activity in blood plasma of ewe lambs after exposure to chlorine in drinking water. Bull Vet Inst Pulawy 48: 81-84

Tice EM, Eastridge ML, Firkins JL 1993: Raw soybeans and roasted soybeans of different particle sizes. 1. Digestibility and utilization by lactating cows. J Dairy Sci 76: 224-235

Tice EM, Eastridge ML, Firkins JL 1994: Raw soybeans and roasted soybeans of different particle sizes. 2. Fatty acid utilization by lactating cows. J Dairy Sci 77: 166-180

Veira DM, Charmley LL, Charmley E, Lee AJ 2001: The effect of feeding soybean oil to mid-lactation dairy cows on milk production and composition and on diet digestion. Canadian J Anim Sci 81: 425-428

Vrzgula L et al. 1990: Metabolic disorders in farm animals and their prevention (in Slovak), $2^{\text {nd }}$ edition, Bratislava, Príroda, $503 \mathrm{p}$.

Wildman EE, Jones GM, Wagner PE, Boman RL, Troutt HF, Lesch TN 1982: A dairy cow body condition scoring system and its relationship to selected production characteristics. J Dairy Sci 65: 495-501

Yasuda J, Syuto B, Too K, Ohfuji S 1989: Lactate dehydrogenase isoenzyme patterns in bovine liver tissue. Japanese J Vet Sci 51: 733-739 